\title{
Pengembangan Lembar Kerja Siswa Berbasis Inkuiri Terbimbing Untuk Siswa SMP Negeri Nuba Arat Pada Materi Kelompok Tumbuhan
}

\author{
Cornelia Dua Kotin, Yohanes Nong Bunga, Mansur S \\ Program Studi Pendidikan Biologi, Fakultas Keguruan dan Ilmu Pendidikan, Universitas Nusa Nipa, \\ Maumere, 86111, Indonesia
}

Email:Uma.Sandy910@gmail.com

\begin{abstract}
Abstrak. Penelitian ini dilatari oleh kemampuan siswa dalam memecahkan masalah masih tergolong lemah, kurangnya keaktifan siswa saat pembelajaran berlangsung dan minimnya literatur cetak yang menyebabkan kemampuan literasi siswa sangat lemah. Penelitian bertujuan untuk mengembangkan Lembar Kerja Siswa (LKS) berbasis inkuiri terbimbing pada materi tumbuhan bagi siswa SMP Negeri Nuba Arat. Penelitian ini merupakan penelitian pengembangan atau Recearch and Development (R\&D) dengan menggunakan model 4D (Define, Design, Develope, and Dessiminate). Dalan penelitian ini, peneliti melakukan beberapa tahap yaitu, analisis awal, analisis tugas, analisis konsep, spesifikasi tujuan, penyusunan tes, pemilihan media dan pemilihan model LKS. Selanjutnya peneliti melakukan validasi produk, perbaikan produk, ujicoba kelas kecil dan menginformasikan kepada siswa serta guru IPA di SMP Negeri Nuba Arat terkait LKS yang sudah dikembangkan. Hasil validasi ahli terhadap produk yang dikembangkan memiliki skor 2,80 untuk ahli materi dan 3,25 untuk ahli media. Validator atau ahli juga memberikan saran terhadap LKS yang dikembangkan berupa perbaikan penempatan gambar, layout dan kesalahan penulisan. Selain itu skor tanggapan siswa dan guru pada saat uji coba kelas kecil yakni 84,71 untuk tanggapan siswa dan 90,07 untuk tanggapan guru. Berdasarkan hasil validasi ahli, perbaikan saran dan skor tanggapan subjek penelitian, maka LKS berbasis inkuiri terbimbing pada materi tumbuhan dinyatakan layak dan dapat digunakan dalam pembelajaran IPA di SMP Negeri Nuba Arat.
\end{abstract}

Kata Kunci: 4D, Inkuiri Terbimbing; Lembar Kerja Siswa, Validasi

\section{Pendahuluan}

Pendidikan memiliki peran penting dalam upaya menciptakan sumber daya manusia yang berkualitas. Pendidikan merupakan suatu faktor kebutuhan dasar untuk setiap manusia, karena melalui pendidikan upaya meningkatkan kesejahteraan rakyat dapat diwujudkan. Menurut Suryosubroto (2010), Pendidikan merupakan usaha yang sengaja dan terencana untuk membantu perkembangan potensi dan kemampuan anak agar bermanfaat bagi kepentingan sebagai individu dan sebagai warga negara/masyarakat. Upaya memenuhi tujuan tersebut dengan cara memilih isi (materi), strategi kegiatan, dan teknik penilaian yang sesuai.

Ilmu Pengetahuan Alam (IPA) merupakan mata pelajaran yang mempelajari tentang alam semesta serta segala sesuatu yang ada di dalamnya. Permendiknas No 22 Tahun 2006 menyatakan, IPA bukan hanya penguasaan kumpulan pengetahuan yang berupa fakta konsep atau prinsipprinsip saja tetapi juga merupakan 
suatu proses penemuan. Penggunaan media dapat mendukung kegiatan siswa dalam proses pembelajaran IPA. Penerapan pendidikan IPA Biologi di sekolah menengah bertujuan agar siswa paham dan menguasai konsep alam. Pembelajaran ini juga bertujuan agar siswa dapat menggunakan metode ilmiah untuk menyelesaikan berbagai persoalan alam. Pendidikan IPA Biologi berperan penting dalam meningkatkan mutu pendidikan terutama dalam menghasilkan siswa yang berkualitas yang mempunyai pemikiran kritis dan ilmiah (Adinugraha, 2011).

Berdasarkan observasi di SMPN Nuba Arat Kecamatan Kangae, terlihat rendahnya kemampuan menalar dan semangat belajar siswa. Kondisi ini dapat dilihat dari masih rendahnya kemampuan berpikir logis dan memecahkan masalah. Selain itu siswa cenderung terlihat pasif dalam proses pembelajaran. Kemampuan siswa masih rendah dalam memahami konsep, dan kurangnya sumber belajar yang dimiliki siswa sehingga siswa hanya mengharapkan penjelasan guru. Oleh karena itu, perlu adanya Lembar Kerja Siswa (LKS) yang menarik dalam pelaksanaan pembelajaran sebagai sarana belajar mandiri untuk siswa. LKS adalah lembaran-lembaran yang berisi perintah yang harus dikerjakan oleh peserta didik, dan langkah-langkah untuk menyelesaikan suatu tugas (Mayasari, dkk. 2015). LKS merupakan salah satu media pembelajaran alternatif untuk membantu siswa dalam menemukan konsep yang dipelajari. Pengetahuan konsep siswa dapat diperoleh melalui kegiatan belajar secara sistematis, mengembangkan sikap ilmiah, keterampilan proses, dan membangkitkan minat siswa dalam mengikuti pembelajaran. Trianto
(2011), menyatakan LKS memuat sekumpulan kegiatan mendasar siswa untuk memaksimalkan pemahaman dalam upaya membentuk kemampuan dasar sesuai indikator pencapaian yang ditempuh. Pengetahuan siswa diberdayakan melalui penyediaan media belajar pada setiap kegiatan eksperimen sehingga situasi belajar lebih bermakna dan berkesan lebih baik pada pemahaman siswa. Muatan materi setiap LKS pada kegiatannya diupayakan dapat mendukung hal itu.

Model inkuiri merupakan salah satu bentuk pendekatan pembelajaran yang berpusat pada siswa. Menurut Gulo (2004), inkuiri adalah suatu rangkaian kegiatan belajar mengajar yang melibatkan secara maksimal seluruh kemampuan siswa untuk mencari dan menyelidiki secara sistematis, kritis, logis, analitis, sehingga siswa dapat merumuskan sendiri penemuannya. Sumantri dan Permana (2001) menyatakan bahwa inkuiri merupakan cara penyajian pelajaran yang memberi kesempatan kepada siswa untuk menemukan informasi dengan bantuan guru.

Penelitian yang dilakukan oleh Selviana, dkk. (2016) dan Dewi, dkk. (2013) menyatakan bahwa LKS berbasis inkuiri terbimbing perlu dikembangkan dan digunakan untuk semua siswa. Apriliayana, dkk. (2012) menyatakan bahwa LKS berbasis inkuiri terbimbing pada materi pencemaran lingkungan dalam upaya melatih keterampilan berfikir kritis siswa dinyatakan sangat layak yaitu mendapat respon oleh siswa sebesar $87,53 \%$ dikategorikan sangat baik untuk dikembangkan. Ambarsari, dkk. (2012) menunjukan pengaruh metode inkuiri terbimbing terhadap keterampilan proses sains pada pelajaran Biologi SMP. Meskipun demikian, penelitian 
tersebut belum membahas khusus pengembangan LKS dengan materi tumbuhan di SMP Negeri Nuba Arat.

\section{Metode}

Penelitian telah dilaksanakan di SMP Negeri Nuba Arat Kecamatan Kangae pada bulan Juli-Desember 2019. Model yang digunakan dalam penelitian ini adalah metode penelitian dan pengembangan atau Research and Development (R\&D). Model penelitian yang digunakan dalam penelitian ini adalah model pengembangan 4-D.

\section{Hasil dan Pembahasan}

Penelitian ini menghasilkan sebuah produk berupa Lembar Kerja Siswa (LKS) berbentuk cetak atau hardcopy dan tanggapan siswa dan guru terhadap LKS materi tumbuhantumbuhan yang dikembangkan. Pada tahap Define atau pendefinisian, peneliti melakukan observasi di SMP Negeri Nuba Arat selama dua hari. Observasi dilakukan khusus pada siswa kelas VII. Hasil observasi menunjukkan bahwa rata-rata siswa memiliki usia yang sama, latar belakang pengetahuan yang sama. Buku pegangan siswa sangat terbatas sehingga siswa mengalami kesulitan untuk memenuhi literasi membaca. Soal yang dikerjakan siswa pada buku pegangan siswa didominasi oleh soal pilihan ganda. Selain itu, peneliti menganalisis pengembangan LKS sesuai dengan tuntutan kurikulum 2013.

diatas, peneliti berdiskusi dan menentukan spesifikasi LKS yang akan dikembangkan yakni penggunaan inkuiri terbimbing dalam mempelajari materi tumbuhan pada setiap kegiatan pembelajaran yang ada.
Peneliti memilih model ini karena setiap tahapannya lebih sistematis dan sesuai untuk pengembangan perangkat pembelajaran. Model pengembangan 4-D terdiri dari 4 tahap utama yaitu; Define (pendefenisian), Design (perancangan), Develop (pengembangan), Disseminate (penyebaran) (Trianto, 2011).

Tahap design atau perancangan, peneliti merancang instrumen tes berdasarkan rumusan tujuan pembelajaran. Pemilihan media dan sumber belajar yang disesuaikan dengan analisis tugas, karakteristik siswa, dan ketersediaan fasilitas. Materi kelompok tumbuh-tumbuhan dirancang dalam dua kegiatan pembelajaran. Setiap kegiatan pembelajaran mencakup kompetensi yang berbeda. LKS yang dikembangkan tersedia dalam format cetak. Siswa dapat menyelesaikan materi kelompok tumbuhan dengan melalui tahapan pembelajaran dalam inkuiri terbimbing. Tahapan-tahapan tersebut adalah perumusan masalah, membuat hipotesis, merancang percobaan, melakukan percobaan, mengumpulkan data dan menganalisis data dan terakhir membuat kesimpulan (Tangkas, 2012). Pengembangan LKS sampai dengan tahap ini disebut sebagai draft I.

Tahap pengembangan selanjutnya yaitu tahap develope atau pengembangan. Draft I selanjutnya divalidasi oleh dua orang validator atau ahli yaitu validator media dan validator materi. Hasil validasi dari validator 
diperoleh mengenali kevalidan dan saran dari ahli (Tabel 1 dan Tabel 2).

Rata-rata skor kevalidan

berdasarkan penilaian validator materi adalah 2,80 termasuk dalam kriteria cukup valid dan validator media sebesar 3,25 termasuk dalam kriteria sangat valid. Sebuah buku dikatakan memiliki validitas apa bila buku tersebut memenuhi kriterium (Arikunto, 2013). Saran dari validator/ahli berupa penempatan gambar, layout, dan kesalahan penulisan. Peneliti kemudian melakukan revisi pada penempatan gambar, layout, dan kesalahan penulisan pada perangkat LKS yang mana hasil revisi perangkat ini disebut sebagai draft II (Gambar 1).

Konsep II materi kelompok tumbuhan yang telah dikembangkan selanjutnya dilakukan ujicoba pada kelas kecil. Pada kelas kecil ini peneliti menggunakan subjek coba adalah siswa kelas VII SMP Negeri Nuba Arat sebanyak 10 orang dan satu orang guru IPA. Guru IPA menggunakan LKS materi kelompok tumbuhan berbasis inkuiri terbimbing dalam pembelajaran di kelas, yang dihadiri oleh 10 orang siswa.

\section{Berdasarkan analisis} responden dalam hal ini guru dan siswa kelas kecil (10 orang) diperoleh hasil bahwa LKS berbasis inkuri terbimbing pada materi kelompok tumbuhan termasuk dalam kategori sangat baik. Skor tangapan siswa sebesar 84,71 dan skor tanggapan guru sebesar 90,07. Hal ini menunjukkan bahwa LKS berbasis inkuri terbimbing pada materi kelompok tumbuhan layak untuk digunakan dalam pembelajaran.

Skor tanggapan guru dan siswa pada uji coba kelas kecil memberikan informasi bahwa LKS berbasis inkuri terbimbing pada materi kelompok tumbuhan dirancang dengan tahapan pembelajaran yang jelas sehingga membantu peserta didik dalam upaya menguasai materi pelajaran. Sejalan dengan pendapat Hidayanti dan Utami (2016) yang menyatakan bahwa pengembangan LKS dapat dijadikan sebagai media pembelajaran siswa.

Pada penelitian ini, peneliti tidak melanjutkan dengan uji coba kelas besar karena keterbatasan waktu yang dimiliki. Kegiatan pembelajaran selanjutnya akan digunakan untuk menyelesaikan materi Sistem Organisasi Kehidupan.

Tahap Disseminate, pada tahap ini peneliti melakukan sosialisasi kepada seluruh siswa kelas VII SMP Negeri Nuba Arat untuk dapat menggunakan LKS berbasis inkuri terbimbing pada materi kelompok tumbuhan yang dikembangkan. Sosialisasi dilaksanakan pada jam istirahat baik dilaksanakan secara berkelompok maupun secara individu. Selanjutnya apabila ada peneliti lanjutan yang berminat dapat melakukan ujicoba pada kelas besar dan pembenahan hingga LKS yang dikembangkan ini benar-benar siap digunakan.

Tabel 1. Hasil Validasi LKS oleh Ahli Materi

\begin{tabular}{clc}
\hline Nomor & \multicolumn{1}{c}{ Komponen/Indikator } & Skor \\
\hline 1 & Kelayakan Isi & 2,77 \\
2 & Kelayakan Penyajian & 2,75 \\
3 & Kelayakan Bahasa & 2,89 \\
\hline \multicolumn{2}{c}{ Rata-rata Skor } & $\mathbf{2 , 8 0}$ \\
\hline
\end{tabular}


Tabel 2. Hasil Validasi LKS oleh Ahli Media

\begin{tabular}{clc}
\hline Nomor & \multicolumn{1}{c}{ Komponen/Indikator } & Skor \\
\hline 1 & Desain Cover & 3,43 \\
2 & Desain Isi & 3,33 \\
3 & Letak Gambar & 3,00 \\
\hline \multicolumn{2}{c}{ Rata-rata Skor } & $\mathbf{3 , 2 5}$ \\
\hline
\end{tabular}

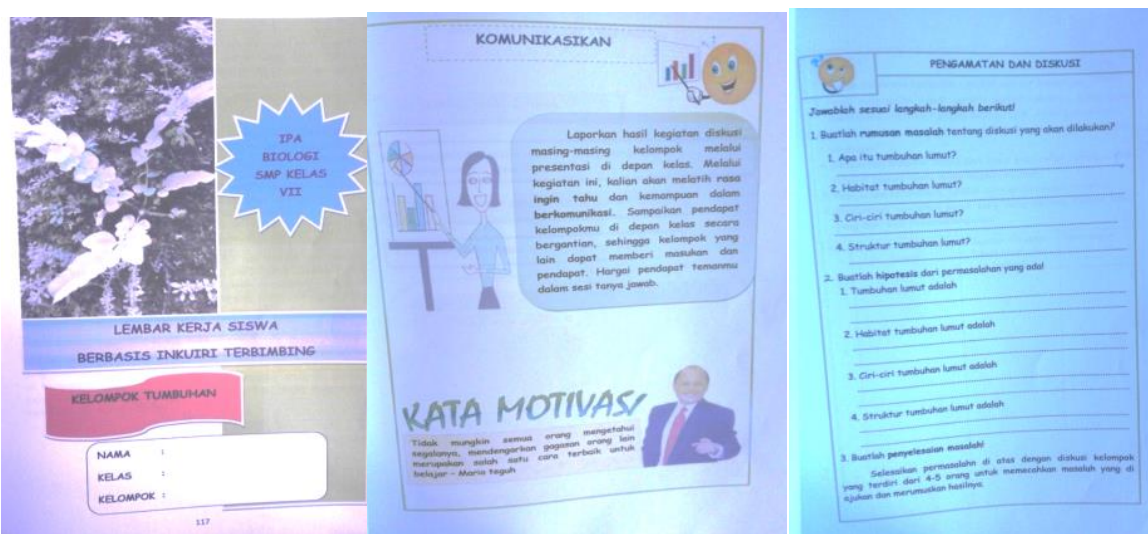

Gambar 1. Lembar Kerja Siswa (LKS) Berbasis Inkuiri Terbimbing yang Telah Diperbaiki

\section{Kesimpulan}

Lembar Kerja Siswa (LKS) berbasis inkuiri terbimbing pada materi kelompok tumbuhan termasuk dalam kategori valid dan layak digunakan dalam pembelajaran. Pernyataan tingkat kevalidan ini berdasarkan hasil penilaian validator materi dan validator media. Berdasarkan analisis tanggapan siswa dan guru pada uji coba kelas kecil dapat dinyatakan bahwa LKS yang dikembangkan dinyatakan layak dan dapat digunakan dalam pembelajaran IPA di SMP Negeri Nuba Arat.
Peneliti memberikan saran kepada bapak/ibu guru IPA di SMP Negeri Nuba Arat agar selalu melakukan inovasi dan variasi dalam pembelajaran. Hal ini perlu dilakukan agar pengalaman belajar siswa lebih kontekstual. LKS berbasis inkuiri terbimbing pada materi kelompok tumbuhan yang dikembangkan ini perlu dilanjutkan lagi khususnya pada ujicoba kelas besar dan tahap disseminate, sehingga kesempurnaan pengembangan dapat tercapai 


\section{Acknowledgements}

Peneliti menyampaikan terima kasih kepada Christina T. Herlina Moa, S.Pd yang telah bersedia menjadi Validator LKS berbasis inkuiri terbimbing pada materi kelompok tumbuhan yang dikembangkan. Selain itu ucapan terima kasih juga disampaikan kepada siswa/i SMP Negeri Nuba Arat kelas VII yang telah bersedia menjadi subjek penelitian dalam uji coba kelas kecil.

\section{Daftar Pustaka}

1. Adinugraha, F., "Penerapan Problem Solving Dengan Game Pohon Pengetahuan Untuk Meningkatkan Aktivitas Dan Hasil Belajar Siswa Pada Materi Ekosistem di Kelas VII C SMP 1 Purworejo," Skripsi, Universitas Kristen Indonesia, 2011.

2. Ambarsari, W., Slamet, S dan Maridi, "Penerapan Pembelajaran Inkuiri Terbimbing Terhadap Keterampilan Proses Sains Dasar Pada Pelajaran Biologi Siswa SMP Kelas VIII SMP N 7 Surakarta," Jurnal Pendidikan Biologi, vol. 5, no. 1, p. 81 - 95, 2013.

3. Apriliyana, U., Fitrihadayati, $\mathrm{H}$, dan Rahardjo, "Pengembangan Perangkat Pembelajaran Berbasis Inkuiri Pada Materi Pencemaran Lingkungan Dalam Upaya Melatih Keterampilan Berpikir Kritis Siswa Kelas X SMA," BioEdu, vol. 1, no. 3, p. 39 44, 2012.

4. Dewi, Narni L., N. Dantes. Dan I. W. Sadia, "Pengaruh Model Pembelajaran Inkuiri Terbimbing Terhadap Sikap IImiah Dan Hasil Belajar IPA," Journal Program Pascasarjana Universitas Pendidikan Ganesha, vol. 3, no. 1, p. 1 - 10, 2013.

5. Hidayanti, D. \& Utami, T. H. "Pengembangan Lembar Kegiatan Siswa (LKS) Matematika dengan Pendekatan Saintifik pada Pokok Bahasan Garis Singgung Lingkaran Untuk SMP Kelas VII," Jurnal IImiah Pendidikan Citra Bakti, vol. 3, no. 1, p. $42-56,2016$.

6. Mayasari, H., Syamsurizal, dan Maison, 2015. "Pengembangan Lembar Kerja Siswa (LKS) Berbasis Karakter Melalui Pendekatan Saintifik Pada Materi Fluida Statik Untuk Sekolah Menengah Atas," [Online]. Available: https://www.neliti.com/id/journals/edusains-jurnal-pendidikan-matematika-dan-ilmu-pengetahuan-alam-universitas-jember.

[Accessed: 23 Maret 2019].

7. M. Sumantri, dan Permana, J, Strategi Belajar Mengajar. Bandung : CV Maulana, 2001.

8. Selviana, D., Susanti. R, dan Iswari, R. S, "Pengembangan LKS Berbasis Inkuiri Terbimbing Pada Materi Struktur Dan Fungsi Jaringan Tumbuhan Di SMP," Unnes Journa of Biology Education, vol. 5, no. 2, p. 123 - 128, 2016.

9. Suryosubroto, Proses Belajar Mengajar di Sekolah. Jakarta : Rhineka Cipta, 2010.

10. Tangkas, I. M, "Pengaruh Implementasi Model Pembelajaran Inkuiri Terbimbing Terhadap Kemampuan Pemahaman Konsep dan Keterampilan Proses Sains Siswa Kelas X SMAN 3 Amlapura," Tesis, Program Pascasarjana Universitas Pendidikan Ganesha, 2012. 
11. Trianto, 2011. Model-model pembelajaran inovatif berorientasi konstruktivitis. Jakarta : Prestasi Pustaka.

12. W. Gulo, Strategi Belajar Mengajar. Jakarta : PT. Gramedia Widiasarana Indonesia, 2004. 